\title{
Biochemical profile of blood in naturally occurring Sarcocystis infection in cattle
}

\author{
Vytautas Januškevičius ${ }^{1}$, Gražina Januškevičienè ${ }^{2}$, Antanas Banys ${ }^{3}$, \\ Jurgita Dailidavičiené ${ }^{4}$, Albina Aniulienè ${ }^{1}$ \\ Lithuanian University of Health Sciences, ${ }^{1}$ Department of Veterinary Pathobiology, \\ ${ }^{2}$ Department of Food Safety and Quality, ${ }^{3}$ Large Animal Clinic, \\ ${ }^{4}$ Department of Anatomy and Physiology, Kaunas, Lithuania \\ Received January 8, 2018 \\ Accepted June 27, 2018
}

\begin{abstract}
The aim of this study was to determine the biochemical blood indicators in Lithuanian Black-and-White cattle with regard to the intensity of their infection with Sarcocystis spp. In total 945 bull muscle samples and 120 blood samples were used for the analysis. Aspartate aminotransferase (AST), alkaline phosphatase (ALP), and alanine aminotransferase (ALT) were increased in infected animals relative to uninfected animals. The AST levels differed significantly between the no infection, low, and moderate infection groups $(P<0.05)$; ALP differed between the no infection and moderate infection groups $(P<0.05)$; and ALT differed between the no infection, low infection and intense infection groups $(P<0.05)$. Total protein levels were higher than physiological limits and differed significantly between the no infection, low infection and intense infection groups $(P<0.05)$. Iron levels were at the lowest physiological limits and differed significantly between the no infection and low infection groups, as well as between the low infection and intense infection groups $(P<0.05)$. Triglyceride levels were at their physiological limits, and differed significantly between all examined groups $(P<0.05)$. The results show that changes in the biochemical markers ALP, AST and ALT are related to the intensity of the Sarcocystis spp. infection.
\end{abstract}

Bulls, sarcocysts, serum, enzymes

Some Sarcocystis spp. species are important pathogens of humans and of domestic and wild animals. Studies conducted in different countries confirm the high prevalence of Sarcocystis spp. in cattle (Domenis et al. 2011; Aissi et al. 2013; Vangeel et al. 2013; Moré et al. 2014; Meistro et al. 2015). The genus Sarcocystis includes parasites of birds, reptiles and mammals, and has an obligatory life cycle of two hosts, in which the intermediate host is usually herbivorous or omnivorous and the final hosts are predators (Kutkienè et al. 2012). Sarcocystis spp., including zoonotic species, are parasites in many species of animals in Europe and cause economic losses due to carcass rejection. Symptoms of the disease are usually expressed to a greater extent in intermediate hosts, and heavy infections have economic importance because of the inferior quality and smaller quantity of meat produced by infected animals (Taylor et al. 2010). Modern farming systems contribute to the spread of this disease, i.e. keeping animals in dense conditions and allowing minimal movement with gas exchange, thermoregulation and microclimate disorders on farms have a negative influence on the animal's body condition and immunity to disease. It has been found that the adaptation of an animal to changing climatic conditions leads not only to a fall in production but also in disease resistance. In such conditions the number of sarcocystosis cases increases and the course of other diseases becomes more severe (Januškevičius et al. 2016). Infections with the Sarcocystis genus are asymptomatic for intermediate hosts, although there are cases of acute sarcocystosis with clinical symptoms such as weakness, anorexia, diarrhoea, weight loss, muscle twitching, central nervous system disorders and others, in rare cases ending even in the death of the 
animal (Daugschies et al. 2000; More et al. 2011; More et al. 2013). Particularly severe symptoms occur in those individuals whose immune system is weakened (Velas quez et al. 2008). Morphological diagnosis of Sarcocystis spp. is difficult. Using light microscopy to identify $S$. cruzi, S. hirsuta and $S$. heydorni is more straightforward. Mature $S$. hirsuta cysts are macroscopic, whereas the cysts of other species are usually seen under a microscope. Short protrusions of $S$. heydorni are invisible under a microscope, whereas $S$. cruzi forms thin microscopically visible protrusions. Since $S$. bovini, S. bovifelis and $S$. hominis are very similar morphologically, morphological methods should be combined with molecular ones for identification (Chiesa et al. 2013; Gjerde 2016). Based on the morphology of the cysts, $S$. cruzi and $S$. heydorni have thin-walled cysts, and $S$. bovini, S. bovifelis, S. hirsuta and S. hominis have thick-walled cysts (Dubey et al. 2015; Hu et al. 2016; Gjerde 2016). In the absence of accurate criteria for assessing the intensity of Sarcocystis spp. infection in cattle, there is no possibility of undertaking an objective veterinary sanitation evaluation of the slaughtered products. By monitoring Sarcocystis spp., searching for new diagnostic methods, and collecting and systematising information on the prevalence of this disease in food-producing animals, it is possible to draw up a list of food products that pose a risk to human health. Haematological data for cattle with sarcocystosis are limited. Blood enzyme activity such as creatinine kinase (CK), aspartate aminotransferase (AST), lactate dehydrogenase (LDH), alanine aminotransferase (ALT), $\gamma$-glutamyl transferase (GGT) and sorbitol dehydrogenase (SDH) were studied in experimental cases of sarcocystosis in cattle approximately three decades ago (Fayer and Johnson 1975; Jungmann et al. 1977; Prasse and Fayer 1981; Dessouky et al. 1984; Nevole et al. 1986). In the past decade scientific data about the activity of blood enzymes in experimental sarcocystosis cases in pigs have been presented (Reiner et al. 2002; Hepp 2006; Reiner et al. 2009; Hübner-Weitz 2010). According to Dede et al. (2014), biochemical properties of blood are important in diagnosing the disease, assessing its effects on the body, and predicting the course of the disease and determining the treatment. At the moment there are no adequate measures with which to assess the state of health of animals infected with sarcocysts. The aim of this study was to relate the biochemical blood parameters in Lithuanian Black-andWhite bulls to the prevalence and intensity of infection of Sarcocystis spp.

\section{Materials and Methods}

Sarcocystis spp. infection was evaluated in Lithuanian Black-and-White cattle aged 20-24 months that had been bred, reared and slaughtered in Lithuania. In total 945 bull muscle samples and 120 blood samples were used for the analysis. Sarcocystosis was diagnosed by means of the compressor-microscopic method by examining $1 \mathrm{~g}$ of oesophagus and $1 \mathrm{~g}$ of diaphragm muscles from each animal, which revealed that $88.89 \%$ of bulls were infected by Sarcocystis spp. Blood samples for biochemical analysis were taken after pre-slaughter examination from animals that showed no clinical symptoms specific to the abovementioned infection, and these were delivered to the laboratory within $2 \mathrm{~h}$. Blood samples were centrifuged ( $5 \mathrm{~min}$ at $3000 \mathrm{rpm}$ ). Top layer serum $(0.5-1.5 \mathrm{ml})$ was collected by Pasteur pipette (Einweg - Pasteurpipetten, Carl Roth GmbH, Germany) into $1.5 \mathrm{ml}$ test tubes (Eppendorf, Hamburg, Germany) and stored in a $-20{ }^{\circ} \mathrm{C}$ freezer until examination. For further analysis selected blood serum samples were taken from bulls in which Sarcocystis spp. infection had been confirmed by the compressor-microscopic method. All blood serum samples were analysed in an automatic Selectra Junior biochemical analyser (Vital Scientific NV, 2006, Netherlands).

When identifying Sarcocystis spp. morphologically, the size and shape of the cyst as well as the cell wall structure were observed. A Nikon ECLIPSE 80i microscope and INFINITY3 video analysis system were used for the microscope analysis. The invasion intensity was determined according to the method suggested by Bogush and Pyshko (1976). The bulls were divided into four groups, $\mathrm{n}=30$ in each group, by Sarcocystis spp. infection intensity, i.e. 0 cysts - no infection; 3-5 cysts - low infection; 15-27 cysts - moderate infection; 45-75 cysts - intense infection. Biochemical tests were performed using Spinreact (Spain) reagents. The amounts of urea, AST, ALT, ALP, iron, creatinine, triglycerides and total proteins in the bulls' blood were determined. The results were compared to the physiological levels according to data in the literature (Kahn and Lin e 2010). Muscle samples (m. phrenicus) were fixed in $10 \%$ formalin $(\mathrm{pH} \mathrm{7.3)}$ at the slaughterhouse. Paraffin blocks were made using Shandon Pathcentre and TES 99 Medite Medizintechnik equipment. Serial 4- $\mu \mathrm{m}$ sections of each sample were prepared using a Sakura Accu-Cut SRM microtome for routine haematoxylin and eosin (HE) staining. The 
statistical analysis was carried out using SPSS Statistic Version 20. The measures used were the arithmetic mean of one random variable $(\mathrm{M})$ and the standard deviation. A single factor dispersion analysis using ANOVA was performed with the aim of distinguishing differences in the intensity of infection in the groups under study. The averages of differences were evaluated using Fisher's least significant difference (LSD) criteria. The relationships between the studied blood indicators were assessed by calculating the linear Pearson correlation coefficient.

\section{Results}

According to the microscopic analysis of native muscle preparations, two morphological types of cysts were evaluated (Plate I, Fig. 1a,b). One type was thin and long with hair-shaped outgrowths and was therefore evaluated to be $S$. cruzi. The majority of cysts were of this morphological type. Meanwhile other cysts were of a cigar shape with finger-like growths of the wall.

The cigar-shaped cysts with finger-like outgrowths could belong to $S$. bovifelis, S. bovini or S. hominis. It was not possible to identify Sarcocystis spp. species using a microscopic analysis of cigar-shaped sarcocysts with finger-like outgrowths. According to Domenis et al. (2011), each cyst with a thick wall should be identified as S. hominis. Based on the fact that there have been no cases of acute bovine sarcocystosis in Lithuania to date, it can be argued that bovine infections by this species are not harmful to their health. A histopathological examination of muscles after being stained with $\mathrm{HE}$ revealed differences in the intensity of Sarcocystis spp. invasion - from single to numerous cysts. Sarcocystis spp. cysts in the muscle tissue produce inflammation around the muscles, as well as inflammation among the cysts, with infiltration of mononuclear cells (neutrophils, lymphocytes, eosinophils, plasma cells) and degeneration and necrosis of muscle fibres.

The mean values of the blood properties measured in this study are shown in Table 1.

Table 1. The dynamics of blood indicatorrs in all experimental bull groups.

\begin{tabular}{|c|c|c|c|c|c|c|c|c|c|}
\hline Group & $\begin{array}{c}\mathrm{n} \\
\mathrm{mmol} / \mathrm{l}\end{array}$ & $\begin{array}{l}\text { Urea, } \\
/ 1 \quad \mu \mathrm{kat} / 1\end{array}$ & $\begin{array}{l}\text { AST, } \\
\mu \mathrm{kat} / 1\end{array}$ & $\begin{array}{l}\text { ALT, } \\
\mu \mathrm{kat} / \mathrm{l}\end{array}$ & $\begin{array}{c}\text { ALP, } \\
\mathrm{mmol} / \mathrm{l}\end{array}$ & $\begin{array}{l}\text { Iron, } \\
\mu \mathrm{mol} / 1\end{array}$ & $\begin{array}{c}\text { Creatinine, } \\
\mathrm{mmol} / \mathrm{l}\end{array}$ & $\begin{array}{l}\text { Triglycerides, } \\
\text { proteins, g/l }\end{array}$ & Total \\
\hline $\begin{array}{l}\text { No } \\
\text { infection }\end{array}$ & 30 & $5.22 \pm 0.18$ & $1.97 \pm 0.07^{\mathrm{ab}}$ & $0.74 \pm 0.06^{\mathrm{a}}$ & $3.53 \pm 0.22^{\mathrm{a}}$ & $0.017 \pm 0.001^{\mathrm{a}}$ & $131.9 \pm 5.21$ & $0.18 \pm 0.01^{\mathrm{a}}$ & $72.6 \pm 1.95^{\mathrm{a}}$ \\
\hline $\begin{array}{l}\text { Low } \\
\text { infection }\end{array}$ & 30 & $5.23 \pm 0.19$ & $2.24 \pm 0.13^{\mathrm{bd}}$ & $1.04 \pm 0.05^{\mathrm{b}}$ & $3.96 \pm 0.25^{\mathrm{a}}$ & $0.024 \pm 0.001^{\mathrm{b}}$ & $138.2 \pm 3.16^{\mathrm{a}}$ & $0.22 \pm 0.008^{b}$ & $77.1 \pm 0.54^{b}$ \\
\hline $\begin{array}{l}\text { Moderate } \\
\text { infection }\end{array}$ & 30 & $4.98 \pm 0.27$ & $3.19 \pm 0.37^{c}$ & $0.92 \pm 0.07$ & $4.81 \pm 0.28^{b}$ & $0.018 \pm 0.001^{\mathrm{a}}$ & $124.8 \pm 4.12^{b}$ & $0.23 \pm 0.02^{b}$ & $76.8 \pm 1.49$ \\
\hline $\begin{array}{l}\text { Intense } \\
\text { infection }\end{array}$ & 30 & $5.17 \pm 0.25$ & $2.83 \pm 0.29^{\mathrm{dc}}$ & $1.03 \pm 0.05^{b}$ & $4.29 \pm 0.33$ & $0.019 \pm 0.001^{\mathrm{a}}$ & $133.1 \pm 4.22$ & $0.24 \pm 0.01^{\mathrm{b}}$ & $78.0 \pm 1.68^{b}$ \\
\hline
\end{tabular}

Aspartate aminotransferase (AST), alkaline phosphatase (ALP) and alanine aminotransferase (ALT) were increased in the infected animals relative to the other groups. The AST levels differed significantly between the no infection, low, and moderate infection groups $(P<0.05)$, ALP differed between the no infection and moderate infection groups $(P<0.05)$ and ALT differed between the no infection, low infection, and intense infection groups $(P<0.05)$. Total protein levels were higher than the physiological limits and differed significantly between the no infection, low infection, and intense infection groups $(P<0.05)$. Iron levels were at the lowest physiological limits and differed significantly between the no infection and low infection groups, as well as between the low infection and 
intense infection groups $(P<0.05)$. Triglyceride levels were at their physiological limits and differed significantly between the groups infected with Sarcocystis spp. compared to the no infection group $(P<0.05)$. Urea and creatinine levels were at their physiological limits. Urea levels did not differ significantly between groups, but creatinine levels differed significantly between the low infection and moderate infection groups $(P<0.05)$.

Interrelations between blood serum indicators of the examined bull groups were calculated (Table 2), revealing that total protein levels increased as creatinine levels increased. A significant $(\mathrm{r}=0.5, P<0.01)$ correlation of moderate strength was established between these indicators. The strongest relationship $(\mathrm{r}=0.6, P<0.01)$ was established between AST and triglyceride levels. The amount of triglycerides increased significantly with the increase in AST $(P<0.01)$. In animals with moderate levels of infection a negative relationship was established between ALP and urea $(\mathrm{r}=-0.45, P<0.01)$. When urea levels increased, the amount of ALP decreased $(P<0.01)$. The amounts of creatinine and urea $(\mathrm{r}=0.33, P<0.01)$, and creatinine and ALP $(\mathrm{r}=0.23, P<0.01)$ were more weakly related. Increasing levels of iron in the blood were accompanied by a significant increase in the amount of total proteins $(\mathrm{r}=0.34, P<0.01)$.

Table 2. Interrelations of blood serum indicators of the examined bull groups.

\begin{tabular}{|c|c|c|c|c|c|c|c|}
\hline Indicator & $\begin{array}{c}\text { Urea, } \\
\mathrm{mmol} / \mathrm{l}\end{array}$ & $\begin{array}{c}\text { AST, } \\
\mu \mathrm{kat} / \mathrm{l}\end{array}$ & $\begin{array}{c}\text { ALT, } \\
\mu \mathrm{kat} / \mathrm{l}\end{array}$ & $\begin{array}{l}\text { ALP, } \\
\mu \mathrm{kat} / \mathrm{l}\end{array}$ & $\begin{array}{c}\text { Iron, } \\
\mathrm{mmol} / \mathrm{l}\end{array}$ & $\begin{array}{c}\text { Creatinine, } \\
\mu \mathrm{mol} / 1\end{array}$ & $\begin{array}{c}\text { Triglycerides, } \\
\mathrm{mmol} / \mathrm{l}\end{array}$ \\
\hline $\begin{array}{l}\text { AST, } \\
\mu \text { kat/l }\end{array}$ & -0.067 & 1 & & & & & \\
\hline $\begin{array}{l}\text { ALT, } \\
\mu \mathrm{kat} / 1\end{array}$ & $0.227^{*}$ & 0.120 & & & & & \\
\hline $\begin{array}{l}\text { ALP, } \\
\mu \mathrm{kat} / 1\end{array}$ & $-0.449 * *$ & $0.193 *$ & -0.125 & 1 & & & \\
\hline $\begin{array}{l}\text { Iron, } \\
\mathrm{mmol} / 1\end{array}$ & $0.247 * *$ & $-0.273 * *$ & $0.197 *$ & $-0.219^{*}$ & 1 & & \\
\hline $\begin{array}{l}\text { Creatinine, } \\
\mu \mathrm{mol} / 1\end{array}$ & $0.325^{* *}$ & $-0.290 * *$ & $0.333^{* *}$ & $-0.271 * *$ & $0.492 * *$ & 1 & \\
\hline $\begin{array}{l}\text { Triglycerides, } \\
\mathrm{mmol} / 1\end{array}$ & $0.207^{*}$ & $0.599 * *$ & 0.147 & -0.116 & $0.197 *$ & -0.058 & 1 \\
\hline $\begin{array}{l}\text { Total proteins, } \\
\mathrm{g} / \mathrm{l}\end{array}$ & $0.206^{*}$ & $-0.250 * *$ & 0.065 & 0.065 & $0.341 * *$ & $0.503 * *$ & $-0.198 *$ \\
\hline
\end{tabular}

* $-P<0.05 ; * *$ - $P<0.01$

AST - aspartate aminotransferase, ALT - alanine aminotransferase, ALP - alkaline phosphatase

\section{Discussion}

The ALP activity was most dynamic in bulls with sarcocystosis, and the amount of ALP increased significantly with greater invasion of sarcocysts. Changes in this indicator lead to skeletal muscle, heart muscle and liver disorders (inflammation, necrosis, degeneration). A few decades ago scientists established that Sarcocystis spp. invasion also caused chronic general myositis, vasculitis, hepatitis, cholangitis, myocarditis, and encephalomyelitis. During the histomorphological examination specific changes were found that revealed myositis. Myositis develops after the rupture of meronts and the invasion of myofibres (Dubey 1983). In chronic cases muscle damage occurs (Bogush and Pyshko 1976; Telles de Jesus Filho and Miraglia 1977; Daugschies etal. 1987). If disease is chronic, the ALP 
activity lasts a particularly long time. This was confirmed by Hepp (2006), who found that the ALP activity increased in cases of experimental pig sarcocystosis and that the different levels of activity of this enzyme depend on the pig breed. However, other scientists found that the amount of ALP in the blood was within the reference limits during sarcocystosis (Kixmöller 2004). The amounts of enzyme dynamics in experimental sarcocystosis cases are referred to as alteration processes, as a result of which intracellular enzymes go into the extracellular medium (Daugschies et al. 1990; Hepp 2006). However, HübnerWeitz (2010) found that the levels of ALP were dependent on the intensity of infection and decreased as infection increased. Data from Martin (1996) and Würbel (2009) showed that sarcocystosis in animals causes suffering in pigs, a deterioration in animal welfare, and changes in clinical and chemical indicators. In the case of pig sarcocystosis the amounts of ALP, AST, iron, creatinine, triglycerides and total protein levels were examined, and an increase in the amount of enzymes was observed (Erber and Geisel 1979; Daugschies et al. 1988; Omarov and Esimov 1988; Hepp 2006). After infection of buffalo calves with $S$. fusiformis sporocysts, minor changes were observed in the blood cytology, serum ALP, glutamic oxalacetic transaminase, glutamic pyruvic transaminase, total proteins, urea and glucose of infected buffalo calves (Dessouky et al. 1984). It is thought that increased ALP levels in animals with Sarcocystis infection were caused by the same factors that increased AST levels. In our study there was a significant difference in AST between the no infection, moderate infection, and intense infection groups. An increase in AST levels is associated with merozoite penetration into the muscle during chronic sarcocystosis stages. Similar results were reported by Daugschies et al. (1988). They found that AST increased between 28 and 77 days after infection. Reiner et al. (2002) indicated that AST increased in cases of pig sarcocystosis and that this increase was significant. AST has been reported in the blood of calf sarcocystosis cases by Fayer and Johnson (1975) and Fayer and Prasse (1981), in piglets by Frelier et al. (1979), in sheep by Philipps and Ford (1987) and in buffaloes by Dessouky et al. (1984).

Alanine aminotransferase is a sensitive marker of liver damage. It accumulates mainly in liver cells, and less frequently in the cytoplasm of kidney, heart and skeletal muscle cells. When a cell is damaged, this enzyme is released into the intracellular medium and its activity in blood plasma increases. In the present case the bull muscle could be assumed to be acute and could lead to cholangitis, which may affect the appearance of sarcocystosis, as mentioned above. The total protein concentration in the blood shows the overall state of the animal. In the present study, the total protein levels in infected animal blood were higher than those in the other groups. The total protein concentration is highly dependent on albumin and globulin synthesis and degradation. The total protein concentration in blood increases when a body loses fluids. Having experimentally inoculated cattle with $S$. hirsuta, Dubey (1983) found that the first generation of meronts caused destruction of the endothelial lining of the arteries in the mesentery and gut, and probably caused diarrhoea and dehydration. Triglyceride synthesis in the liver, adipose tissue, the small intestinal mucosa and muscle appeared to be unaffected. Iron levels were lower than the lowest physiological limit in all groups and differed significantly between the no infection, moderate infection and intense infection groups. Many researchers have established that anaemia develops in sarcocystosis. According to Frelier et al. $(1979 ; 1984)$ and Fayer and Prasse (1981), anaemia of acute bovine sarcosystosis is primarily haemolytic. The urea concentration in the blood of the examined bulls was unaffected, and therefore kidney function was deemed not to be disturbed. The dynamics of creatinine levels in the examined groups was unstable and less related to the dynamics of creatinine and the urea amount dynamics $(\mathrm{r}=0.33, P<0.01)$.

In summary, differences in the blood biochemical properties between healthy animals and animals infected with Sarcocystis spp. were evaluated. The AST, ALP, ALT and total 
protein levels were significantly increased in infected animals. The results of this study provide the basis for further examination of methods for the diagnosis of naturally occurring Sarcocystis infection and monitoring bovine herds and testing blood for Sarcocystis infection in early stages.

\section{References}

Aissi M, Harhoura KH, Khuoni F 2013: Prevalence and study of the bovine sarcocystis species in the slaughterhouses of Rouiba (Algiers). J Vet Sci Technol 4: 127

Bogush AA, Pyshko II 1976: Glycogen content of the muscles and liver of pigs infected with Sarcocystis (in Russian). Vet nauka-proizv 14: 173-174

Chiesa F, Muratore E, Dalmasso A, Civera T 2013: A new molecular approach to assess the occurrence of Sarcocystis spp. in cattle and products thereof: preliminary data. Ital J Food Saf 2: 148-151

Daugschies A, Rommel M, Schnieder T, Henning M, Kallweit E 1987: Effects of Sarcocystis miescheriana infection on carcass weight and meat quality of halothane-tested fattening pigs. Vet Parasitol 25: 19-31

Daugschies AT, Schnieder T, Rommel M, Bickhardt K 1988: The effects of Sarcocystis miescheriana infections on blood enzymes and weight gain of stress-sensitive and stress-insensitive pigs. Vet Parasitol 27: 221-229

Daugschies A, Hasche HO, Rommel M 1990: Aktivitäten ausgewählter Enzyme im Blutplasma und in der Muskulatur Sarkosporidien-infizierter Schweine. Mitt Österr Ges Tropenmed Parasitol 12: 131-140

Daugschies A, Hintz J, Henning M, Rommel M 2000: Growth performance, meat quality and activities of glycolytic enzymes in the blood and muscle tissue of calves infected with Sarcocystis cruzi. Vet Parasitol 88: $7-16$

Dede S, Altug N, Deger Y, Ozdal N, Ceylan E 2014: Serum biochemical profile and protein fractions in cattle with Theileriosis. Rev Med Vet 5-6: 137-143

Dessouky MI, Mohamed AH, Nassar AM, Hilali M 1984: Haematological and biochemical changes in buffalo calves inoculated with Sarcocystis fusiformis from cats. Vet Parasitol 14: 1-6

Domenis L, Peletto S, Sasshi L, Clementi E, Genchi M, Felisari L, Felisari C, Mo P, Modesto P, Zuccon F, Campanella C, Maurella C, Guidetti C, Acutis PL 2011: Detection of a morphogenetically novel Sarcocystis hominis like in the context of a prevalence study in semi-intensively bred cattle in Italy. Parasitol Res 109: 1677-1687

Dubey JP 1983: Clinical sarcocystosis in calves fed Sarcocystis hirsuta sporocysts from cats. Vet Pathol 20: 90-98

Dubey JP, Wilpe E, Calero-Bernal R, Verma SK, Fayer R 2015: Sarcocystis heydorni, n. sp. (Apicomplexa: Sarcocystidae) with cattle (Bos taurus) and human (Homo sapiens) cycle. Parasitol Res 114: 4143-4147

Erber M, Geisel O 1979: Untersuchungen zur klinik und pathologie der Sarcocystis suicanis infektion beim schwein. Berl Münch Tierärztl Wschr 92: 197-202

Fayer R, Johnson AJ 1975: Effect of Amprolium on acute sarcocystosis in experimentally infected calves. J Parasitol 61: 932-936

Fayer R, Prasse KW 1981: Hematology of experimental acute Sarcocystis bovicanis infection in calves. i. cellular and serologic changes. Vet Pathol 18: 351-357

Frelier PF, Mayhew IG, Pollock R 1979: Bovine Sarcocystosis: pathologic features of naturally occurring infection with Sarcocystis cruzi. Am J Vet Res 40: 651-657

Hepp S 2006: Phänotypische und genetische Parameter ausgewählter klinischer und klinisch-chemischer Merkmale zur Charakterisierung der Resistenz gegenüber Sarcocystis miescheriana im F2-Modell beim Schwein. Vet Med Diss Gießen, pp 73-78

Hu JJ, Wen T, Chen XW, Liu TT, Esch GW, Huang S 2016: Prevalance, morphology, and molecular characterization of Sarcocystis heydorni sarcocysts from cattle (Bos taurus) in China. J Parasitol 102: 545-548

Hübner-Weitz K 2010: Auswirkungen klinischer und subklinischer Krankheit auf ethologische und klinischchemische Merkmale beim Schwein. Vet Med Diss Gießen, pp 79-86

Januškevičius V, Januškevičienė G, Paulauskas V, Petkevičius S 2016: Prevalence and intensity of sarcosporidia infection in wild clovenhoofed hunted for food in Lithuania. Vet Med Zoot 73: 27-31

Jungmann R, Bergmann V, Hiepe TH. Nedjari T 1977: Untersuchungen zur septikämisch verlaufenden experimentellen Sarcocystis bovicanis-Infektion des Rindes. Mh Vet Med 32: 885-889

Gjerde B 2016: Molecular characterisation of Sarcocystis bovifelis, Sarcocystis bovini n. sp., Sarcocystis hirsuta and Sarcocystis cruzi from cattle (Bos taurus) and Sarcocystis sinensis from water buffaloes (Bubalus bubalis). Parasitol Res 115: 1473-1492

Kahn CM, Line S 2010: The Merck Veterinary Manual 10 ${ }^{\text {th }}$ Edition. Bayr Med LT 2000, 2943 p.

Kixmöller M 2004: Labordiagnostische Referenzbereiche bei unterschiedlichen Schweinerassen sowie histophathologische und immunhistochemische Untersuchung von Gehirnen älterer Sauen und Eber auf transmissible spongiforme Enzephalopathie im Rahmender TSE-Studie. Diss. LMU München

Kutkienė L, Prakas P, Butkauskas D, Sruoga A 2012: Description of Sarcocystis turdusi sp. nov. from the common blackbird (Turdus merula). Parasitology 139: 1438-1443

Martin G 1996: Zur naturwissenschaftlichen Erfassbarkeit von Leiden bei Tieren - eine Einführung. Tierärztl Umschau 51: 131-136 
Meistro S, Peletto S, Pezzolato M, Varello K, Botta M, Richelmi G, Biglia C, Baioni E, Modesto P, Acutis P, Bozzetta E 2015: Sarcocystis spp. prevalence in bovine minced meat: a histological and molecular study. Ital J Food Safety 4: 85-87

More G, Abrahamovich P, Jurado S, Bacigalupe D, Marin JC, Rambeaud M. 2011: Prevalence of Sarcocystis spp. in Argentinean cattle. Vet Parasitol 177: 162-165

More G, Schares S, Maksimov A, Conraths FJ, Venturini MC, Schares G 2013: Development of a multiplex real time PCR to differentiate Sarcocystis spp. affecting cattle. Vet Parasitol 197: 85-94

Moré G, Pantchev A, Skuballa J, Langenmayer MC., Maksimov P, Conraths FJ, Venturini MC, Schares G 2014: Sarcocystis sinensis is the most prevalent thick-walled Sarcocystis species in beef on sale for consumers in Germany. Parasitol Res 113: 2223-2230

Nevole M, Malota L, Koudela B 1986: Catalytic activity of selected serum enzymes in experimental sarcocystosis in calves. Acta Vet Brno 55: 81-84

Omarov BS, Esimov BK 1988: Dynamics of mineral metabolism and catalytic activity of enzymes in the serum of pigs with experimental sarcosporidiosis (in Russian).Vestn S-H Nauki Kazahstana 10: 66-68

Philipps PH, Ford GE 1987: Clinical, haematological and plasma biochemical changes in specified-pathogen-free (Sporozoa) lambs experimentally infected with low numbers of Sarcocystis tenella sporocysts. Vet Parasitol 24: $15-23$

Prasse KW, Fayer R 1981: Hematology of experimental acute Sarcocystis bovicanis infection in calves. II. Serum biochemistry and hemostasis studies. Vet Pathol 18: 358-367

Reiner G, Hübner K, Hepp S 2009: Suffering in diseased pigs as expressed by behavioural, clinical and clinicalchemical traits, in a well-defined parasite model. Appl Anim Behav Sci 118: 222-231

Reiner G, Eckert J, Peischl T, Borchert S, Jäkel T, Mackenstedt U, Joachim A, Daugschies A, Geldermann H 2002: Variation in clinical and parasitological traits in Pietrain. Vet Parasitol 106: 99-113

Taylor MA, Boes J, Boireau P, Boué F, Claes M, Cook AJC, Dorny P 2010: Development of harmonised schemes for the monitoring and reporting of Sarcocystis in animals and foodstuffs in the European Union: EFSA Scientific Report. EFSA, 28 p.

Telles De Jesus Filho M, Miraglia T 1977: Histochemical observations on the Sarcocystis fusiformis cysts in ox hearts. Acta Histochem 59: 160-167

Vangeel L, Houf K, Geldhof P, De Preter K, Vercruysse J, Ducatelle R, Chiers K 2013: Different Sarcocystis spp. are present in bovine eosinophilic myositis. Vet Parasitol 197: 543-548

Velasquez JN, Risio C, Etchart CB, Chertcoff AV, Mendez N, Cabrera MG 2008: Systemic sarcocystosis in a patient with acquired immune deficiency syndrome. Hum Pathol 39: 1263-1267

Würbel H 2009: Ethology applied to animal ethics. Appl Anim Behav Sci 118: 118-127 
Plate I

Januškevičius V. et al.: Biochemical profile ... pp. 205-211

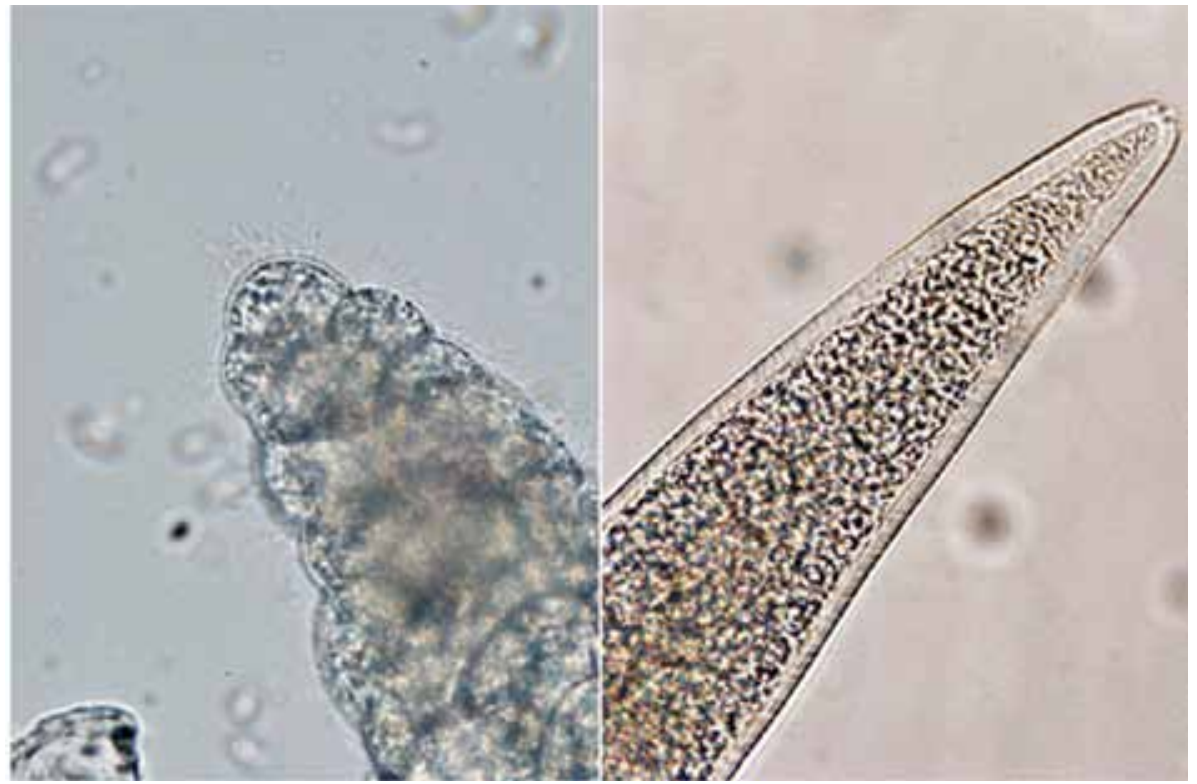

Fig. 1. Two morphological types of cyst in cattle muscles: a) a fragment of a cyst with a hair-shaped outgrowths from the wall, b) a fragment of a cyst with a finger-like outgrowths from the wall. 